„Przekłady Literatur Słowiańskich”. T. 10, cz. 1

ISSN 2353-9763 (wersja elektroniczna)

DOI https://doi.org/10.31261/PLS.2020.10.01.10

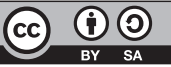

\title{
Kundera światowy? Hrabal peryferyjny? Przekład jako forma promocji?
}

\section{Global Kundera? Peripheral Hrabal? Translation as a Form of Promotion?}

\author{
Wojciech Soliński
}

iD https://orcid.org/0000-0001-8244-3101

UNIVERSITY OF WROCŁAW

wsol@konto.pl

Data zgłoszenia: 18.02 .2019 r. | Data akceptacji: 10.02 .2020 r.

\begin{abstract}
The paper attempts to describe selected aspects of the impact of new concepts (such as history of European literature or history of the world republic of literature) that have entered into the literary and translation discourse and that coexist with the traditional categories such as ancient literature, modern literature, national literature, world literature, synthesis of the history of literature or process of the history of literature. The "confusion of tongues" (confusio linguarum) connected with the emergence of these novel concepts has undoubtedly affected the discipline of translation studies and, in particular, the promotional aspects of translation and self-translation as well as other related phenomena. An interesting role in this discussion is also played by what I refer to as "perspective," from which the incorporation of given works or authors into European literature or world literature is being observed. In two out of the four analyzed works, the French (Parisian) perspective prevails, characteristic of a certain stage of comparative studies that seemed to have lost significance some time ago. The two remaining works, written from the Czech perspective, are addressed to English- and German-speaking readers, respectively.
\end{abstract}

KEYWORDS | history of European literature, literary translation, self-translation, contemporary Czech literature, B. Hrabal, M. Kundera, A. Benoit-Dusausoy, G. Fontaine, P. Casanova, J. Gruša, J. Škvorecký 


\section{Wprowadzenie nie całkiem niepoważne}

W 1976 roku Umberto Eco opublikował w „Corriere della Sera” List z Pontu (Lettera dal Ponto), który w roku 1977 przedrukował zamiast wstępu w swojej książce pt. Dalla periferia dell'impero ( $Z$ peryferiów imperium). List ten był adresowany: „Ad Geraldum Fordum Balbulum, Foederatarum Indianarum ad Occasum Vergentium Civitatum Principem", a jego zdanie inicjalne brzmiało:

A te, Principe e Imperatore, Luce delle Indie Occidentali, Reggitore della Pax Atlantica, al Senato e al Popolo Americano, Ave... o Figlio di Jupiter I Canaveralense... o figlio dell'Apollo di NASA... ${ }^{1}$

Ten gorzkoironiczny tekst miał zwiastować post factum przejście od Pax Romana do Pax Americana, wyznaczając tym samym nowe centrum cywilizowanego świata i nowe jego peryferie.

O wiele wcześniej bohater Portretu artysty z czasów młodości (tak tytuł powieści Joyce’a przełożył Zygmunt Allan) albo Portretu artysty w wieku młodzieńczym (jak później zatytułował swój przekład Jerzy Jarniewicz) umieścił na stronie przedtytułowej podręcznika do geografii następującą sekwencję: „Stephen Dedalus - Klasa początkowa - Gimnazjum Clongloves Wood Sallins - Hrabstwo Kildare - Irlandia - Europa - Świat - Wszechświat”.

I jeszcze cytat z rodzimego gruntu: „Polska to obwarzanek: kresy urodzajne, centrum - nic”. Zdanie to miał wypowiedzieć Józef Piłsudski do biskupa żytomierskiego Ignacego Duba-Dubowskiego w pociągu, po odjeździe z Mińska Mazowieckiego do Warszawy, 18 maja 1920 roku.

A na koniec dwie opinie, wydaje się, obiegowe: „Wszystko, co najlepsze w literaturze polskiej, powstało na emigracji” oraz „Literatura emigracyjna ma swój znaczący udział w czeskiej kulturze literackiej”.

\section{Uwagi ogólne}

W przekładoznawczym dyskursie literaturoznawczym obok tradycyjnych kategorii, takich jak: literatura starożytna, literatura nowożytna, literatura narodowa czy literatura powszechna, upowszechniają się, w różnym stopniu definiowalne, koncepty literatury Europy Środkowej, literatury Europy. W dyskursie historycznoliterackim oprócz „wskrzeszanych” terminów, jak: synteza historycznoliteracka, proces historycznoliteracki, pojawiają się nowe koncepty: historia literatury

1 U. Eco, 1977: Dalla peryferia dell'impero. Milano, Bompiani, s. 7. 
europejskiej, historia literatury światowej, a ściślej - tzw. światowej republiki literatury. Nie wdając się w szczegółowe rozważania, uznać je można za rezultaty takich odmiennych, odległych w czasie i przestrzeni procesów, jak utrata centrum z jednej strony, a globalizacja - z drugiej. Modelowanie wspomnianych konceptów prezentuje się jako skomplikowany proces interdyscyplinarny, niejednorodny, kapryśny, nieznośnie elastyczny, „kresowy” itp. ${ }^{2}$

W artykule nie będę analizował wkładu obu interesujących mnie tu pisarzy Milana Kundery i Bohumila Hrabala - w formowanie i utrwalanie konceptu Europy Środkowej. Rzecz jest doskonale znana i opisana. Wspomnę tylko, że dla Kundery Europa Środkowa to właściwie pojałtańska, zniewolona przez stalinowsko-leninowski komunizm Europa Wschodnia. Tymczasem Hrabal zarysowuje jej czasowe i przestrzenne kresy nie tyle głębiej, ile z pewnością szerzej, posługując się przy tym często i chętnie „kluczem galicyjskim”.

Przedmiotem artykułu jest próba opisu wpływu, jaki swego rodzaju confusio linguarum, towarzyszące upowszechnianiu się tych konceptów, wywierało na szeroko rozumianą translatologię, ze szczególnym uwzględnieniem przekładu, autoprzekładu i zjawisk im towarzyszących. Zastanowienia wymaga również to, co określam nieprecyzyjnym mianem „punktu widzenia”, z którego obserwowany jest proces przenikania poszczególnych dzieł czy autorów do „literatury europejskiej” czy „światowej”. W obu analizowanych w artykule pracach dominuje zdecydowanie francuski, dokładniej paryski, punkt widzenia, charakterystyczny dla pewnego etapu badań komparatystycznych, który - jak się wydaje - uznano za szczęśliwie miniony.

Nie bez znaczenia jest także refleksja nad promocyjną mocą przekładu, szczególnie interesująca w kontekście rozważań na temat tłumaczenia jako procesu zbliżania kultur. Ową promocyjną funkcję przekładu opatruję w tytule znakiem zapytania, ponieważ podobnie jak wątpliwy jest proces zbliżania kultur, czyli wymiana wartości, poprzez tłumaczenie stanowiące przykład „kulturalnej okupacji” (np. obowiązkowe przekłady literatury radzieckiej w czasach PRL), tak samo wątpliwy (niezależny od jakości przekładu) jest jego efekt promocyjny, nie następuje wtedy to, co określiłem kiedyś mianem „krzyżowego zapylenia”

2 Syntetycznie i przejrzyście ilustruje ten problem z czeskiego punktu widzenia antologia tekstów na temat różnych konceptów Europy Środkowej: J. Trávníček, red., 2009: $V$ kleštích dějin. Střední Evropa jako pojem a problem. Brno, Host. Por. też numer szósty z roku 2011 „České literatury”, poświęcony problematyce Europy Środkowej. Kresowość rozumiem tutaj, za Jackiem Kolbuszewskim, jako nieokreśloność granic. Zawsze wtedy, kiedy słowo kresy pisane jest z małej litery. Por. J. Kolbuszewski, 1995: Kresy. Wrocław, Wydawnictwo Dolnośląskie, s. 12-19.

3 Por. W. Soliński, 1987: Przekładanie - zbliżanie kultur czyli wymiana wartości. W: Idem: Przekład artystyczny a kultura literacka. Komunikacja i metakomunikacja literacka. Wrocław, Wydawnictwo Uniwersytetu Wrocławskiego, s. 89-97. 
Jednakże bezpośrednim powodem powstania tego tekstu była obserwacja, którą zasygnalizowałem w roku 2013, kiedy pisząc o „pozaczeskich” dolach i niedolach prozy Hrabala po jego śmierci, zwracałem uwagę, że gorliwie i uważnie czytany jest na gruncie środkowoeuropejskim, szczególnie w Polsce, na Węgrzech, a także we Włoszech, co nie dziwi, ale także w Japonii i Chinach, co zaskakuje, trudno bowiem posądzać Japończyków i Chińczyków o posługiwanie się w lekturze wytrychem Europy Środkowej, a zatem „to już zapewne rezultat uroku uniwersalności przesłania, jaki rzuca również w te rejony świata czeski pisarz" ${ }^{4}$.

Nieco później, kiedy dane mi było zapoznać się, notabene po polsku, z opublikowanymi we Francji, kolejno w latach 1993 i 1999, pracą grupy francuskojęzycznych literaturoznawców pt. Literatura Europy. Historia literatury europejskiej oraz książką Pascale Casanovy Światowa republika literatury, mogłem dodać do wzmiankowanej obserwacji uwagę, że Paryża przecież Hrabal nie podbił. Obie wspomniane publikacje ustawiam tu w porządku chronologicznym, zgodnie $\mathrm{z}$ datami pierwszych wydań. Nie zawsze jest to porządek wygodny, ale zachowujący pewien, chce się rzec: meandryczny, sposób docierania do nich ${ }^{5}$. Obie te publikacje wskazują nadto wyraźnie na rolę przekładu w promowaniu poszczególnych dzieł/autorów; w obu widoczna jest promocyjna moc tłumaczeń, szczególnie na język francuski. Z prac tych wynika niezbicie, że podboju Paryża (który nie udał się Hrabalowi) dokonał inny autor - urodzony w Brnie pisarz morawski, czeski, środkowoeuropejski, wreszcie francuski, ergo: światowy, a mianowicie Milan Kundera, który wyemigrował z kraju urodzenia i osiadł we Francji, wreszcie porzucił w twórczości język ojczysty na rzecz języka francuskiego. W tym miejscu rodzi się podejrzenie, że awans twórczości pisarza „na salony" literatury europejskiej/światowej możliwy był wyłącznie dzięki takiej, niełatwej przecież, decyzji.

Inny wniosek, jaki można wysnuć z lektury przywołanych prac, sprowadza się do stwierdzenia, że brak tłumaczeń musi skazywać na peryferyjność/ „zaściankowość" dzieła pisarzy tworzących w tzw. małych językach ojczystych/macierzystych, i to niezależnie od walorów estetycznych, oryginalności, ponadczasowości tych utworów. Wniosek ten jednak wydaje się tyleż łatwy do sformułowania, ile trudny do udowodnienia, ponieważ przekład niewątpliwie czasem promocję ułatwia, ale o niej nie przesądza, prowadząc niektórych autorów do porzucenia języka ojczystego/macierzystego jako środka artystycznego wyrazu na rzecz języka „wielkiego", czyniącego ową promocję znacznie łatwiejszą.

4 W. Soliński, 2013: Bohumila Hrabala sprawa polska (i inne sprawy). Wrocław, Atut, s. 9.

5 Przypomnieć należy, że książka P. Casanovy w polskim przekładzie ukazała się w roku 2017, a Literatura Europy - w roku 2009. 
A przecież z punktu widzenia pisarza tworzącego w „wielkim” języku kwestia ta (paradoksalnie?!) wygląda podobnie, $\mathrm{z}$ tą różnicą, że skazany jest on na mozolne torowanie sobie drogi do literatury europejskiej czy światowej wśród mnogości dzieł napisanych w tymże języku. Oczywiste wydaje się, że punkt widzenia kultury literackiej „małego” języka odgrywa tu rolę decydującą, analogicznie do punktu widzenia kultury języka „wielkiego” (tu: francuskiego).

\section{Kundera w Światowej republice literatury}

Starając się określić stopień obecności literatury czeskiej, a właściwie jej dwóch znaczących reprezentantów, przyjąć musiałem do wiadomości, że w książce P. Casanovy Hrabala zwyczajnie nie ma. Jest - nie twierdzę jednak, że natomiast - Milan Kundera. Literaturę czeską w Światowej republice literatury reprezentują trzej przedstawiciele. Są to w kolejności alfabetycznej: František Čelakovský, Milan Kundera i Jaroslav Seifert. Hrabal nie jest, jak już wspomniałem, obywatelem tej republiki; jest w niej zwyczajnie nieobecny, bo też ta republika nie jawi się jako nadzwyczajnie demokratyczna.

F. Čelakovský wspomniany jest w rozdziale Wynalezienie literatury jako jeden z tych pisarzy słowiańskich, którzy zostali rażeni tym, co autorka określiła mianem „efektu Herdera”, który uchodził za romantycznego piewcę Słowian domagających się prawa i konieczności pisania w językach ojczystych. Czeskiego pisarza zaprezentowano tu jako wydawcę trzech tomów ludowych pieśni słowiańskich i ogromnego zbioru słowiańskich przysłów i porzekadeł.

Nazwisko J. Seiferta pojawia się w Światowej republice literatury w rozdziale Fabryka tego, co uniwersalne, poświęconym promocyjnej mocy Literackiej Nagrody Nobla. Figuruje tam obok innych laureatów, takich jak: Pablo Neruda, Eugenio Montale, Claude Simon czy Dario Fo, jako świadectwo tego, że Komitet Noblowski na swój sposób uzupełnia albo dubluje werdykty wydane wcześniej w Paryżu, które to werdykty jednocześnie niejako unieważniają wybory dokonane przez instytucje londyńskie ${ }^{6}$.

Ani w przypadku F. Čelakovskiego, notabene profesora Uniwersytetu Wrocławskiego w latach 1842-1849, ani w przypadku J. Seiferta nie znajdziemy uwag na temat przekładów ich dzieł na „wielkie” języki. Wolno, jak się zdaje, mniemać, że F. Čelakovský znalazł się w tej publikacji w rezultacie „boomu

6 Por. P. Casanova, 2017: Światowa republika literatury. E. Gałuszka, A. Turczyn, przeł. Kraków, Wydawnictwo Uniwersytetu Jagiellońskiego, s. 231. 
na słowiańszczyznę" ogłoszonego przez Herdera, a J. Seiferta wepchnęła tutaj instytucjonalna moc Literackiej Nagrody Nobla.

Na tak zarysowanym tle obecność Kundery można uznać za „agresywną”. Pojawia się on już w Przedmowie do wydania z roku 2008 jako jeden z licznego grona literatów reprezentujących kraje określane przez autorkę mianem wysoko upolitycznionych. Autor Żartu miał w gorzkim eseju o literackich niedolach tzw. małych krajów, zatytułowanym Niekochane dziecko rodziny ${ }^{7}$, uświadomić P. Casanovie, że w owych krajach:

honor zbiorowości opiera się na prostym wzmiankowaniu czyjegoś nazwiska lub nazwy własnej; że reputacja grupy [...], zależy częściowo od opinii obcego na temat narodowej klasyki; i wreszcie że każde słowo o literaturze narodowej tego kręgu musi być starannie wyważone. Czytelnicy bowiem, tak samo jak pisarze, mają rozwiniętą tę specyficzną nadwrażliwość, która najczęściej cierpi nie z powodu jej zewnętrznego zakwestionowania, ale wskutek presji wewnętrznej.

Na stronie 250 nazwisko Kundery wymienione jest między innymi obok Danila Kiša, Thomasa Bernharda, Carlosa Fuentesa, Julia Cortázara, Octavia Paza czy Antonia Tabucchiego, czyli pisarzy mających potwierdzać „trwałość konsekracji udzielanych przez paryskie instytucje”.

W części zatytułowanej Literacka nędza, w której mowa jest o literaturze „małych” krajów, autorka przywołuje opinię Kundery na temat małych narodów, wyjętą ze Zdradzonych testamentów:

Małe narody. Ten koncept nie jest ilościowy; oznacza on pewną sytuację, przeznaczenie: małym narodom nieznane jest szczęśliwe poczucie bycia tu od zawsze i na zawsze. [...] Zawsze spotykały się z obcesową ignorancją ze strony wielkich $\mathrm{i}$ ich istnienie jest wiecznie zagrożone i podawane w wątpliwość; albowiem ich istnienie jest wątpliwością9

W rozdziale Małe literatury P. Casanova powołuje się na opinię Kundery o swego rodzaju służbie, do jakiej zmuszony jest pisarz - obywatel małego narodu. Zapewne zacytowane słowa łatwiej było napisać po francusku niż po czesku:

$\mathrm{W}$ wielkiej rodzinie małego narodu artysta jest zatem skrępowany na wiele sposobów, przez wiele nitek. Gdy Nietzsche hałaśliwie pomiata charakterem niemieckim, gdy Stendhal oznajmia, że od swej ojczyzny woli Włochy, nie obraża się

7 Por. M. Kundera, 2008: Zdradzone testamenty. M. Bieńczyk, przeł. z franc. Warszawa, PIW, s. 163-177.

8 P. Casanova, 2017: Światowa republika literatury..., s. 15.

9 M. Kundera, 2008: Zdradzone testamenty..., s. 172. 
żaden Niemiec, żaden Francuz; gdyby Grek lub Czech ośmielił się powiedzieć coś podobnego, jego rodzina wyklęłaby go jako ohydnego zdrajcę ${ }^{10}$.

Przytoczone zdania są bez wątpienia tyle gorzkie, ile efektowne, ale czy w świetle niektórych artefaktów ich znaczenie nie blednie chociaż trochę? Wystarczy wspomnieć tylko rzeźbę Edvarda Černego Sikający na dziedzińcu Muzeum Franza Kafki w Pradze. I wziąć pod uwagę, że ma ona przecież upamiętniać wejście Czech do Unii Europejskiej.

Warto dodać w tym miejscu, bo nie czyni tego P. Casanova, że ową służebność wyjaśnia Kundera nie na własnym przykładzie, ale odwołując się do sytuacji Gombrowicza interpretowanego, a właściwie bronionego przez Lakisa Proguidisa przed krytykami niepolskimi, starającymi się wyjaśnić niepolskim czytelnikom uwikłanie polskiego pisarza poprzez jego „polonizację", a nawet „repolonizacje”, i spychającymi go przy okazji w to, co Proguidis nazywa „małym kontekstem” narodowym, zamiast podkreślać jego dogłębną znajomość „wielkiego kontekstu", jakim jest dla czeskiego, piszącego to po francusku, pisarza modernistyczna powieść światowa. Kundera przyznaje wszakże, że tak odczytywany Gombrowicz nie usiłuje zmienić tej opinii poprzez porzucenie w twórczości języka polskiego na rzecz innego „większego” (?!) języka, który mógłby pomóc odczytaniu jego dzieła w „wielkim kontekście” modernistycznej powieści światowej. Również w Zdradzonych testamentach znajdujemy uwagi na temat upartej wierności kompozytora Leoša Janáčka, który skazuje cudzoziemskich śpiewaków na łamanie sobie języka przy wykonywaniu arii w języku czeskim ${ }^{11}$.

Sam Kundera, podobnie jak Cioran, Beckett czy Strindberg, postrzegany jest przez P. Casanovę jako ten, który porzucił własny język ojczysty na rzecz języka francuskiego, jako skolonizowany, skrajnie upolityczniony. Nie wydaje się jednak, by do przypadku Kundery - chociaż wymieniony jest obok takich pisarzy, jak: Rachid Boudjedra, Jean-Joseph Rabearivelo, Ngũgĩ wa Thiong’o, Wole Soyinka - stosowała się przytoczona przez autorkę opinia Alberta Memmiego, tak opisującego los pisarzy pochodzących z dawnych kolonii:

Ojczysty język poddanego kolonizacji [...] nie posiada żadnej godności, ani w kraju, ani pośród innych ludów. Jeśli skolonizowany chce zdobyć jakiś zawód, mieć swoje, zyskać prawo obywatelstwa i żyć w świecie, musi przede wszystkim ugiąć się przed językiem obcych, kolonizatorów, swoich panów. Żyjąc w sytuacji konfliktu językowego, doświadcza upokorzenia, zmiażdżenia swego ojczystego języka. I tę pogardę, opartą na obiektywnych podstawach, w końcu czyni swoją ${ }^{12}$.

10 Ibidem, s. 173.

11 Ibidem, s. 172-176.

12 Cyt. za: P. Casanova, 2017: Światowa republika literatury..., s. 376-377. 


\section{Kundera i Hrabal w Literaturze Europy}

W tej bardzo niezwyczajnej i zapewne kontrowersyjnej historii literatury europejskiej czeskiej literaturze poświęcono bez porównania więcej miejsca (w sumie około 30 stron). Na osobne sylwetki w dziale mistrzów poszczególnych epok zasłużyli Jan Hus i Jan Ámos Komenský, a wśród wyróżnionych pisarzy współczesnych znajdziemy Milana Kunderę. Dla chorujących na polskość wspomnę, że wśród mistrzów zamieszczono sylwetki: Jana Potockiego, Adama Mickiewicza, Witolda Gombrowicza, a w gronie wyróżnionych pisarzy współczesnych - Tadeusza Konwickiego (literaturze polskiej poświęcono około 40 stron).

Wszyscy trzej pisarze czescy obecni w pracy Casanovy, czyli Čelakovski, Kundera i Seifert, pojawiają się również w Literaturze Europy. Ten ostatni, jak już wspomniałem, nie znalazł się ani wśród mistrzów, ani wśród wyróżnionych pisarzy współczesnych. Ale to nie powinno dziwić, poeci europejscy w omawianej publikacji nie są szczególnie wyróżniani.

Rzeczą charakterystyczną dla sposobu istnienia w Literaturze Europy dzieła Hrabala jest jego występowanie niejako w cieniu twórczości Milana Kundery. Po raz pierwszy na kartach publikacji pisarze ci spotykają się w rozważaniach nad neorealizmem, w których trzykrotnie wydane Śmieszne miłości (Smešné lásky, 1963, 1965, 1968) wskazują na swoisty sposób widzenia spraw ludzkich. Łącząc wizję tragikomiczną, ironiczną i filozoficzną, ukazują poprzez relacje erotyczne stan obyczajów społeczeństwa „anormalnego”, poddanego formalnie ciężkim regułom, przeciw którym Kundera buntuje się w roku 1967 powieścią Żart (Žert), wysuwając zasadnicze oskarżenie przeciwko społeczeństwu, które niszczy jednostki. Dopiero wtedy bardzo spóźniony debiutant Bohumil Hrabal, w wieku czterdziestu dziewięciu lat, może wydać swoje dawne opowiadania w zbiorach Bawidułki (Pábitelé, 1964), Sprzedam dom, w którym już nie chcę mieszkać (Inzerát na dům ve kterém už nechci bydlet, 1965) i Pociągi pod specjalnym nadzorem (Ostře sledované vlaky, 1966). Warto zacytować konkluzję fragmentu poświęconego Hrabalowi, nie tylko z uwagi na jego styl zapewne zależny także od sprawności polskiego tłumacza i redaktora, którzy cytując polski przekład fragmentu opowiadania pod tytułem Zupełny Kafka (Kafkárna), zmieniają prawidłowo przełożoną „ściętą krew” („sedlou krev”) na „krew świętą”:

Karty tych opowiadań, pozornie prostych, zapełniają zwyczajni ludzie, dość naturalni w zachowaniach: dużo mówiący, mający zbyt wybujałą wyobraźnię, spotykający się najczęściej w przyjemnych [!?] piwiarniach, daleko od zebrań 
partii. Te szczególne „hrabalowskie” postacie żyją swoim rzeczywistym życiem nieco z dala od społeczeństwa ${ }^{13}$.

W rozdziale zatytułowanym Realizm socjalistyczny $i$ dysydenci Kundera i Hrabal wymienieni są wśród innych twórców uczestniczących w tym, co autorzy opracowania nazywają odnową literacką lat 1960-1969. Ta odnowa znajduje swój wyraz najpierw w poezji i w teatrze, a potem w powieściach Edvarda Valenty i Josefa Škvoreckiego, stawiających w centrum zainteresowania jednostkę i odrzucających wszelką ideologię. Oprócz poetów Vladimíra Holana i Jaroslava Seiferta, należących do starszego pokolenia, oraz dramaturga Václava Havla najliczniejszą grupę stanowią w Czechosłowacji prozaicy, tacy jak Kundera, Hrabal, Škvorecký czy Pavel Kohout. Poezję Seiferta zawartą w tomikach: Koncert na ostrově (Koncert na wyspie, 1965), Odlewanie dzwonów (Odlévání zvonư, 1967) czy Halleyova kometa (Kometa Halleya, 1967) określa się jako dalekie odejście od jego wcześniejszej poezji intymistycznej, melodyjnej i regularnej, zaskakującej szorstkością słów i obrazów wypełniających te uwolnione od regularności wiersze.

Omawiając europejski postmodernizm, zwrócono uwagę na to, że w krajach Europy Środkowej i Wschodniej sytuacja z reguły jest inna, przede wszystkim dlatego, że całkowicie odmienna jest rola literatury w systemach totalitarnych. Bardzo często sprzeciw wobec literatury oficjalnej prowadzi do odrzucenia „sensu” i „spójności”. Literatura „nieoficjalna” przypomina więc nierzadko awangardę lub klasyczny modernizm, a nie ma postmodernistycznego charakteru tak się dzieje na przykład w Polsce. Jednakże są wyjątki od tej „odmienności” Europy Wschodniej względem Zachodniej. Otóż sprzeciw wobec literatury akceptowanej oficjalnie - jak dowiadujemy się z francuskiego opracowania może prowadzić też do powstania form ironicznych lub pełnych odwołań do samych siebie, jak w twórczości Milana Kundery, pochodzącego z istniejącej do końca 1992 roku Czechosłowacji. Pojęcie „nieznośnej lekkości bytu” Kundery stało się klasyczną metaforą doświadczania przez bohatera świata w optyce postmodernistycznej.

Nazwisko jednego z najwybitniejszych przedstawicieli prozy czeskiej tego czasu - Josefa Škvoreckiego - pojawia się w Literaturze Europy przy omawianiu przemian zachodzących w prozie czeskiej, która rozwija się w trzech nurtach oficjalnym, podziemnym i emigracyjnym - i stanowi kontynuację przemian zachodzących w niej od początków XX wieku. Pisarz ten w swych powieściach, opowiadaniach psychologicznych i biograficznych oraz quasi-kryminałach

13 Por. A. Benoit-Dusausoy, G. Fontaine, red., 2009: Literatura Europy. Historia literatury europejskiej. H. Abramowicz et al., przeł. Gdańsk, Słowo/Obraz Terytoria, s. 864-865. 
odświeża - jak dowiadujemy się z opracowania - tradycję Karela Čapka, wzbogacając ją o inspiracje angielskie i amerykańskie.

Bohumil Hrabal zaznacza swoją obecność w Literaturze Europy - jako piewca codzienności - za pośrednictwem takich narracji, określonych mianem wyrafinowanych, jak Obsługiwałem angielskiego króla (Obsluhoval jsem anglického krále, 1975) czy Zbyt głośna samotność (Př́liš hlučná samota, 1976). Liczne formy krótkiej prozy narracyjnej, w duchu Nerudy, Haška i Čapka, wynikają z niepewnej sytuacji politycznej. Opowiadania, nowele, szkice i felietony piszą tacy autorzy, jak Hrabal, Kundera, Škvorecký czy Klíma. Ludvík Vaculík wspomniany jest jako niekwestionowany mistrz felietonu, któremu nadał poetycką formę.

Jednakże reprezentantem nowego typu literatury biograficznej w prozie czeskiej, określonego mianem autofikcji, jest we francuskim opracowaniu wyłącznie Milan Kundera i jego powieść Nieśmiertelność (tytuł wersji francuskiej: L'Immortalité, 1990, tytuł wersji czeskiej: Nesmrtelnost, 1988). W jej fikcyjnym świecie, obracającym się wokół prawdziwego ,ja” narratora, autor zgromadził liczne postaci „historycznie rzeczywiste” — od Goethego do Hemingwaya. Tak można odnaleźć ten zadziwiający, fragmentaryczny dyskurs, który wykracza poza granice samego dyskursu i który może dokładnie odzwierciedlać wszechświat jednostki.

Charakterystyczne dla omawianej - cennej przecież — publikacji jest jej zakończenie zatytułowane Współczesność. Kierunki i pisarze, na które składają się krótkie (najczęściej jednostronicowe) szkice, zebrane pod tytułem Pisarze wspótcześni, dotyczące przedstawicieli literatury poszczególnych krajów Europy. Warto wspomnieć, że Czechy reprezentuje Milan Kundera (autor szkicu: Jan Rubeš), Słowację Pavel Vilikovský (autorka szkicu: Diana Lemay), a Polskę Tadeusz Konwicki (autorka szkicu: Maryla Laurent, znana propagatorka i tłumaczka jego książek na język francuski).

Cechą charakterystyczną tych „wizytówek” jest wysuwanie na pierwszy plan różnie, chociaż głównie translatorsko, uzasadnianej „europejskości” zaprezentowanych pisarzy, co w przypadku Pétera Esterházego prowadzi do paradoksu. Oto węgierski autor, który w roku 1990 oddał literacki hołd Hrabalowi, pisząc powieść pod tytułem Hrabal könyve (polski przekład: Księga Hrabala, 2003), obecny jest w tym zestawieniu, podczas gdy dla pisarza, któremu ten hołd oddał - jako jednemu z przedstawicieli tradycji literatury absurdu, obok Bułhakowa i Gombrowicza - miejsca zabrakło ${ }^{14}$. 


\section{Kundera i Hrabal z punktu widzenia „małego języka”}

Warto przyjrzeć się także dwóm publikacjom powstałym w kulturze literackiej „małego języka”, skierowanym wszakże do publiczności czytającej „języków wielkich": angielskiego i niemieckiego. Pozycje te nie mają ambicji naukowych opracowań o charakterze historycznoliterackim. Mowa o książkach: Jozefa Škvoreckiego All The Young Men And Woman: A Personal History OfCzech Film (1971) oraz Jiřego Grušy Gebrauchsanweisung Tschechien und Prag $^{15}$. Na ich podstawie można zaobserwować, jak oceniają rolę i miejsce intersujących nas tu pisarzy w europejskiej i światowej kulturze literackiej ich koledzy po piórze.

Zapewne z uwagi na to, że książka Škvoreckiego poświęcona jest filmowi czeskiemu, Hrabal jest w niej zdecydowanie bardziej obecny niż Kundera. Autora Żartu przywołano w kontekście problemów, jakie w roku 1968 miał Jaromil Jireš z przyjęciem do realizacji scenariusza filmu, który napisał na podstawie powieści Kundery. Mimo trudności film został zrealizowany i zdążył jeszcze zdobyć sympatię krajowej widowni; nagrodzono go na festiwalu w Bergamo w roku 1970, a dzięki niespodziewanej „odsieczy” ze strony pewnego komunistycznego krytyka, który „pochwalił Jireša za filmowy Żart, w odróżnieniu od powieściowego”, mógł wprawić w stan niemałej konfuzji autora powieści, który — jak pisze Škvorecký — „był już wtedy przymierzany do roli jednego z przywódców pełzającej kontrrewolucji” ${ }^{16}$. Rzuca się w oczy brak w opracowaniu poważniejszych uwag na temat emigracyjnej aktywności Kundery oraz jego zerwania z językiem czeskim jako językiem twórczości.

Hrabala uważa autor All The Young Men And Woman... za niewątpliwie najbardziej wielbionego czeskiego pisarza lat sześćdziesiątych:

[...] choć od 1970 roku do momentu publicznej samokrytyki w 1975 roku jego książki były zakazane, a potem wydawane tylko w zredukowanych i masakrowanych przez cenzurę wersjach. Najlepszym dowodem stosunku do Hrabala może być zbiór tekstów, jakie na sześćdziesiąte urodziny autora napisali dla niego koledzy po piórze. W powstałej w ten sposób antologii spotkali się praktycznie wszyscy, którzy cokolwiek dziś znaczą w literaturze czeskiej, a ponieważ niemal wszyscy oni mieli zakaz publikacji, więc zbiór ten wyszedł jedynie w samizdacie. Z kolei sam Hrabal też jest klasycznym pisarzem undergroundowym, zarówno w zachodnim znaczeniu tego pojęcia: czyli że zaczynał swą karierę jako

15 Posługuję się polskim przekładem: J. Škvorecký, 2018: Wszyscy ci wspaniali chłopcy i dziewczyny. Osobista historia czeskiego kina. A.S. Jagodziński, przeł. Sejny, Pogranicze; J. Gruša, 2018: Czechy. Instrukcja obstugi. A.S. Jagodziński, przeł. Kraków, Międzynarodowe Centrum Kultury.

16 J. Škvorecký, 2018: Wszyscy ci wspaniali chłopcy i dziewczyny..., s. 217. 
nonkonformista, jak też w owym specyficznym znaczeniu, jakie słowo to nabiera w reżimach autorytarnych: że przez długie lata, niemal do swej pięćdziesiątki, był pisarzem niepublikowanym ${ }^{17}$.

Sam Škvorecký we wstępie do amerykańskiej edycji wyboru opowiadań Hrabala, podpisanym pseudonimem Daniel S. Miritz - oczywistym dla każdego czytelnika jego prozy, nieoczywistym dla komunistycznej cenzury — pisze o ich autorze jako o jednym

z pięciu najlepszych opowiadaczy naszych czasów. Jego jedynym problemem jest tylko to, że pisze w egzotycznym języku, którego nikt nie zna. Gdyby pisał po rosyjsku, siedziałby, co prawda, za kratkami, ale byłby za to w amerykańskich podręcznikach $^{18}$.

Samokrytykę Hrabala określa mianem „zgięcia mu grzbietu”, przy czym dodaje, że zgięto go nie tylko jemu:

W jego twórczości nie ma jednak żadnych śladów lojalności dla reżimu — bo wymuszone podpisy pod politycznymi oświadczeniami w sztuce się nie liczą [...].

Bo jego czytelnicy w większości pozostali mu wierni. Mają świadomość, że nie każdy jest predestynowany do roli męczennika, a w długiej perspektywie - choć ta myśl nie dla wszystkich jest w pełni do przyjęcia - „czyste ręce” nie są aż tak ważne, jak samo dzieło. W końcu, jak napisał Graham Greene w eseju Cnota nielojalności, nawet sam Szekspir ma w swoim dorobku wiersze ku czci osób i czasów, które wcale nie zasłużyły na chwałę ${ }^{19}$.

Bardziej „zrównoważone” są uwagi Grušy charakteryzującego postawę Kundery uwikłanego — „w atmosferze poinwazyjnego kaca” — w stary spór z Vaclavem Hávlem o tzw. czeski los. Zdaniem autora Gebrauchsanweisung Tschechien und Prag, „pisarze spierali się o to, czy nasza próba przyklejenia ludzkiej twarzy do jednego z izmów była unikatem czy farsą". Kundera był zdania, że to wydarzenie znaczące i wyjątkowe, jako próba „odgadnięcia trendu świata”, podczas gdy Havel uważał, że „trendy świata to tylko iluzja, jeśli własny dom nie jest w porządku", i sugerował, by raz wreszcie, od katastrofalnego roku 1948, ten dom posprzątać. Kontynuując, Gruša przypomina, że także później każdy z nich bronił swego zdania:

Kundera w Paryżu jako pisarz światowej sławy (w kraju zazdrośnie umniejszanej), Havel w więzieniu jako autor i polityk, a w końcu jako nasz prezydent w Pradze

17 Ibidem, s. 282.

18 Ibidem, s. 309.

19 Ibidem, s. 311. 
na Hradczanach [...]. Koncepty się raczej nie zmieniły. Kundera - Morawianin - kochał prawdę w czasie teraźniejszym, Havel - Czech - w czasie przyszłym. Te debaty na ziemi nigdy nie zostaną rozstrzygnięte... ${ }^{20}$

W tym kontekście Hrabal prezentowany jest czytelnikowi niemieckiemu jako jeden z twórców „prawdziwie czeskiej prozy i czegoś, co później [...] nazwał pábeni”. A miejsca narodzin pábeni poszukuje nie tylko na szlaku budziejowickiej anabasis Szwejka ${ }^{21}$, ale przede wszystkim w specyficznym języku Pragi, w którym nie chodzi o „żadne bzdury małych ludzików, żadne banalne plotki, ale o przypomnienie niestałości świata”. Gruša nie waha się sięgnąć po myśl Wittgensteina, że „świat to ogół faktów”, by stwierdzić następnie, że Hrabal próbuje ten świat nazwać, „sięgając przy tym do tezaurusa praskiej niemczyzny”, i to właśnie dzięki temu staje się wielkim pábitelem. Autor zauważa, że słowo pábit może pochodzić od fabeln, baffeln albo babbeln i oznacza "gadać”, „paplać”. Nie dostrzega znaczeniowego podobieństwa w czeszczyźnie, bo jego zdaniem:

Pábit to nie to samo co baffeln, podobnie jak knedlík to nie Knödel [...]. Jednak Hrabal nie tylko wybrał mądrze, ale też złożył mały hołd językowi swej żony [...]. A może też mu opowiedziała, że ten sposób mówienia o życiu wziął się prosto z życia, że przyjął się także w niemieckich kawiarniach i winiarniach, więc pábeni można by uznać za wspólną budowlę obu kultur naszej metropolii [...]. Jednak pábitel to trochę więcej niż Baffler [...]. W pábeni pobrzmiewa gdzieś czeski báj (bajka, mit) i bávení (bawienie, rozweselanie). Czyli baśń, nie prawda. Więc właściwie Prawda wcale tu nie zwycięża. A z pewnością nie prawda polityczna [...]. Panuje tu „ja” liryczne. Ale znowu — nie ma żadnego monologu, żadnej monomanii, tylko solowe popisy osobistości, nawet małych czy wręcz malutkich [...]. Chór złożony z obserwatorów mruczy potakująco i upija z kufla. Bo skoro świat to ogół faktów, to jesteśmy tylko jednymi z nich [...]. W naszych czasach - czasach bezgranicznej pychy człowieka, jego trywialności i rozpasania — właściwie już tylko pábitel przywraca światu odpowiednie wymiary ${ }^{22}$.

Obaj cytowani autorzy opisują istotne cechy twórczości Hrabala i Kundery z dwóch punktów widzenia, oddalonych w przestrzeni, ale niezbyt odległych od siebie w czasie. Zwracając się do czytelników literatury czeskiej

20 J. Gruša, 2018: Czechy. Instrukcja obstugi..., s. 275.

21 Na temat skomplikowanego charakteru haszkowskiego rodowodu pábitela por. A. Cosentino, 2015: Rodowód postaci „pábitela”. W: J. Goszczyńska, red.: W poszukiwaniu przerw w zabudowie. W stulecie urodzin Bohumila Hrabala. Warszawa, Wydział Polonistyki Uniwersytetu Warszawskiego, s. 142-147.

22 J. Gruša, 2018: Czechy. Instrukcja obstugi..., s. 76-77, 79. 
komunikujących się na co dzień dwoma „wielkimi językami”, dystansują się wobec literatury ojczystej, przyjmując — bardziej lub mniej świadomie — pozycję autorów wcześniej omawianych publikacji francuskojęzycznych.

Próżno szukać u Škvoreckiego i Grušy uwag na temat przekładów prozy Hrabala i Kundery na język angielski czy niemiecki. Upraszczając nieco zagadnienie, można powiedzieć, że o ile „uniwersalna” proza Kundery przekłada się z języka czeskiego na języki obce bez większych trudności, a z czasem jeszcze łatwiej tłumaczy się z ,uniwersalnego" języka francuskiego, o tyle proza Hrabala dobrze nie tłumaczy się bodaj na żaden obcy czeszczyźnie język (w tym także polski). A przecież powodzeniem czytelniczym cieszy się w Japonii i we Włoszech. Zatem obaj czescy autorzy upatrują uniwersalne powodzenie prozy Hrabala w jej „czeskości”; w jej zakorzenieniu w praskiej czeszczyźnie, otwartej przecież na wpływy praskiej niemczyzny. Przy czym Škvorecký mówiąc o tzw. zginaniu karku, nie waha się rozważać tej kwestii w kontekście anglojęzycznym, odwołując się do opinii Grahama Greena na temat „elastyczności karku” Szekspira.

Zmierzając do konkluzji, warto zwrócić uwagę na polskie przekłady dzieł obu pisarzy z uwagi na ich poetykę, która w znacznym stopniu zależy od tłumaczy: Hrabal nie ma u nas tzw. swojego tłumacza. Jego prozę przyswajało polszczyźnie co najmniej dwudziestu tłumaczy i tłumaczek, co zapewne nie zawsze pozytywnie wpływało na kształt stylistyczny i gatunkowy poszczególnych utworów. Dzieła Kundery z języka czeskiego przekładało tylko czworo tłumaczy. Okoliczności, w jakich doszło do zdominowania przekładów z języka francuskiego przez Marka Bieńczyka, bodaj najlepiej wyjaśnia sam autor Nieśmiertelności w notce Od autora:

Od 1985 do 1987 roku przeredagowałem bardzo gruntownie francuskie przekłady wszystkich moich powieści, pracując nad każdym słowem; od tej pory uznaję ich francuską wersję za własną. Są wśród moich powieści i takie, których wersja francuska satysfakcjonuje mnie nawet bardziej niż czeska. Dotyczy to zwłaszcza Nieśmiertelności, której „słowa kluczowe” były pomyślane po francusku, a wiele rozdziałów (zwłaszcza rozdziałów refleksyjnych) po francusku naszkicowanych. Wiedząc o tym, Marek Bieńczyk zaproponował, aby przekładu na polski dokonać właśnie z języka francuskiego; jego pomysł przyjąłem z zadowoleniem i akceptuję go bez zastrzeżeń ${ }^{23}$.

Konkludując, może zatem warto zaryzykować twierdzenie, że niedoskonałe przekłady prozy Hrabala na języki obce nie są w stanie przeszkodzić w odbiorze „czeskości” tej swoiście uniwersalnej prozy, nawet jeśli, jak wolno mniemać, w znacznym stopniu jej odbiór zakłócają; może także warto przyjrzeć się prob-

23 M. Kundera, 1995: Nieśmiertelność. M. Bieńczyk, przeł. z franc. Warszawa, PIW, s. 391. 
lemowi światowości pisarstwa Milana Kundery w świetle pewnej wypowiedzi Jamesa Joyce'a: „Istota mojego talentu wynika z buntu przeciwko angielskim konwencjom zarówno literackim, jak i każdego innego typu. Nie piszę po angielsku" ${ }^{24}$.

Decyzja Kundery, by nie pisać dalej po czesku, zapewne nie była łatwa, ale niewątpliwie ułatwiła mu wstęp na paryskie salony. Nie dotarł tam Bohumil Hrabal, ale czy nawet ułomne, a przecież liczne, przekłady z języka czeskiego na „wielkie”, a może przede wszystkim na te "niewielkie”, a nawet „egzotyczne” języki nie zapewniły mu statusu pisarza „światowego inaczej”?

\section{Literatura}

Benoit-Dusausoy A., Fontaine G., red., 2009: Literatura Europy. Historia literatury europejskiej. H. Abramowicz et al., przeł. Gdańsk, Słowo/Obraz Terytoria.

Casanova P., 2017: Światowa republika literatury. E. Gałuszka, A. Turczyn, przeł. Kraków, Wydawnictwo Uniwersytetu Jagiellońskiego.

Cosentino A., 2015: Rodowód postaci „pábitela”. W: J. Goszczyńska, red.: W poszukiwaniu przerw w zabudowie. W stulecie urodzin Bohumila Hrabala. Warszawa, Wydział Polonistyki Uniwersytetu Warszawskiego.

Gruša J., 2018: Czechy. Instrukcja obsługi. A.S. Jagodziński, przeł. Kraków, Międzynarodowe Centrum Kultury.

Kundera M., 1995: Nieśmiertelność. M. Bieńczyk, przeł. z franc. Warszawa, PIW.

Kundera M., 2008: Zdradzone testamenty. M. Bieńczyk, przeł. z franc. Warszawa, PIW.

Skibińska E., red., 2004: Gombrowicz i tłumacze. Łask, Leksem.

Soliński W., 2011: Polsko ve střední Evropě Bohumila Hrabala. M. Havránková, přel. „Česká literatura”, 6, s. 899-904.

Škvorecký J., 2018: Wszyscy ci wspaniali chłopcy i dziewczyny. Osobista historia czeskiego kina. A.S. Jagodziński, przeł. Sejny, Pogranicze.

Trávníček J., red., 2009: V kleštích dějin. Střední Evropa jako pojem a problem. Brno, Host.

24 Cyt. za: P. Casanova, 2017: Światowa republika literatury..., s. 463. 


\section{Wojciech Soliński \\ Světový Kundera? Lokalní Hrabal? \\ Překlad jako forma propagace?}

RÉSUMÉ | Práce je pokusem popsat některé aspekty vlivu jež v dyskursu literárnědnem (i překladatelském) maji některe nové koncepty (vedle již zavedených: literatura starověká, literatura novověká, literatura obecná, literárněhistorická synteza, literárněhistorický proces). Konkrétně jde o koncepty historie evropské literatury, historie světové literatury a zejmena světové republiky literatury. To, co vycházi z těchto konceptu (svého druhu confusio linguarum) muselo změnit široce pojatou translatologii, především pokud jde o propagační silu překladu, autopřekladu, atd. Hodno úvahy je rovněž to, co popisuji jako „hledisko”, z něhož je možno pozorovat pronikaní konkretnych děl do „literatury evropské” nebo „literatury světové". Ve dvou ze čtyř analyzovaných prací dominuje francouzské (resp. Pařížské hledisko), které je typické pro jisté období komparatistických studii. O tomto hledisku se soudi, že je již štastně překonáno. Dvě další prace jsou napsány z české perspektivy a obracejí se $\mathrm{k}$ čtenářủm anglo- a německojazyčným.

KLĹCOVÁ SLOVA | historie evropské literatury, literarní překlad, autopřeklad, současná česká literatura, B. Hrabal, M. Kundera, A. Benoit-Dusausoy, G. Fontaine, P. Casanova, J. Gruša, J. Škvorecký

\section{Wojciech Soliński}

\section{Kundera światowy? Hrabal peryferyjny? Przekład jako forma promocji?}

STRESZCZENIE | W artykule podjęto próbę opisania wybranych aspektów oddziaływania nowych koncepcji (takich jak historia literatury europejskiej czy historia światowej republiki literatury), które weszły do dyskursu literackiego i przekładoznawczego i które współistnieją z tradycyjnymi kategoriami, takimi jak literatura dawna, współczesna, literatura narodowa, literatura światowa czy proces historii literatury. „Pomieszanie języków” (confusio linguarum), związane z pojawieniem się tych pojęć powieściowych, niewątpliwie wpłynęło na dziedzinę studiów translatorskich, a w szczególności na promocję przekładu i autoprzekładu oraz na inne zjawiska $\mathrm{z}$ tym związane. Ciekawą rolę w tej dyskusji odgrywa również to, co nazywam „perspektywą," z której obserwuje się włączanie danych utworów lub autorów do literatury europejskiej lub światowej. W dwóch z czterech analizowanych w artykule dzieł dominuje perspektywa francuska (paryska), charakterystyczna dla pewnego etapu badań porównawczych, który, jak się zdaje, już się zakończył. Dwie pozostałe publikacje, napisane z perspektywy czeskiej, są adresowane do czytelników anglo- i niemieckojęzycznych.

SŁOWA KLUCZOWE | historia literatury europejskiej, przekład literacki, autotprzekład, współczesna literatura czeska, B. Hrabal, M. Kundera, A. Benoit-Dusausoy, G. Fontaine, P. Casanova, J. Gruša, J. Škvorecký 
WOJCIECH SOLIŃSKI ｜ prof. dr hab., emerytowany profesor Uniwersytetu Wrocławskiego, były kierownik Zakładu Teorii Literatury w Instytucie Filologii Polskiej UWr. Literaturoznawca, teoretyk literatury, translatolog, tłumacz. Opublikował m.in.: Przekład artystyczny a kultura literacka. Komunikacja i metakomunikacja literacka (1987); Kształty obecności. Recepcja pisarstwa Umberta Eco w polskiej kulturze literackiej (2001); Bohumila Hrabala sprawa polska (i inne sprawy) (2013). Współredagował (z Włodzimierzem Boleckim i Maciejem Gorczyńskim) Współczesne dyskursy konfliktu. Literatura - język - kultura (2015). Przełożył na język polski książkę U. Eco La ricerca della lingua perfetta nella cultura europea - W poszukiwaniu języka uniwersalnego (wyd. 1, 2002), Poszukiwanie języka doskonałego w kulturze europejskiej (wyd. 2, 2013). Publikował też po czesku, po angielsku i po francusku. Z języków czeskiego i słowackiego przekładał teksty naukowe z zakresu nauk humanistycznych. Jako tłumacz literacki zadebiutował przekładem bajki B. Hrabala Kopretina / Złocieńka (2014). 